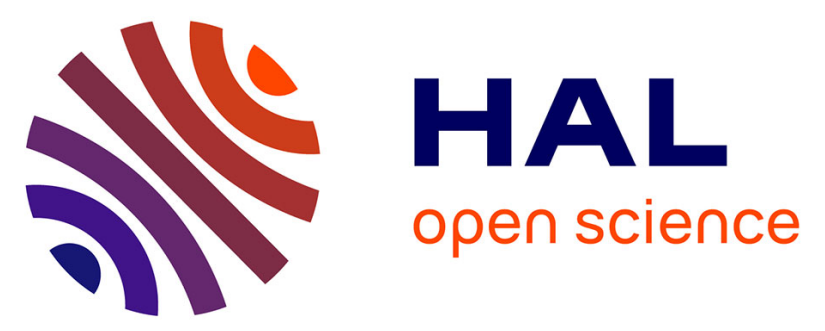

\title{
DYNAMIC BEHAVIOR ANALYSIS OF THE GLOMERULO-TUBULAR BALANCE MEDIATED BY THE EFFERENT BLOOD VISCOSITY
}

Andrea Espinel Rojas, Pablo S. Rivadeneira, Vicente Costanza, Carlos

Amorena

\section{To cite this version:}

Andrea Espinel Rojas, Pablo S. Rivadeneira, Vicente Costanza, Carlos Amorena. DYNAMIC BEHAVIOR ANALYSIS OF THE GLOMERULO-TUBULAR BALANCE MEDIATED BY THE EFFERENT BLOOD VISCOSITY. CCS 2012: 4th International Interdisciplinary Chaos Symposium on Chaos and Complex Systems, Apr 2012, Antalya, Turkey. hal-00718084

\section{HAL Id: hal-00718084 \\ https://hal.science/hal-00718084}

Submitted on 16 Jul 2012

HAL is a multi-disciplinary open access archive for the deposit and dissemination of scientific research documents, whether they are published or not. The documents may come from teaching and research institutions in France or abroad, or from public or private research centers.
L'archive ouverte pluridisciplinaire HAL, est destinée au dépôt et à la diffusion de documents scientifiques de niveau recherche, publiés ou non, émanant des établissements d'enseignement et de recherche français ou étrangers, des laboratoires publics ou privés. 


\title{
DYNAMIC BEHAVIOR ANALYSIS OF THE GLOMERULO-TUBULAR BALANCE MEDIATED BY THE EFFERENT BLOOD VISCOSITY
}

\author{
A. Espinel $^{1}$, P. Rivadeneira ${ }^{2}$, V. Costanza ${ }^{2}$, C. Amorena ${ }^{3}$ \\ ${ }^{1}$ L'UNAM, IRCCYN, UMR CNRS 6597, École Centrale de Nantes, France \\ ${ }^{2}$ Grupo de Sistemas No Lineales, INTEC, UNL-CONICET, Santa Fe, Argentina \\ ${ }^{3}$ Escuela de Ciencia y Tecnología, Universidad Nacional de San Martín, San Martín, Argentina \\ E-mail: Andrea.Espinel-Rojas@irccyn.ec-nantes.fr.
}

\begin{abstract}
$\underline{\text { Context }}$
The nephron is the basic functional and structural unit of the kidney. Its principal function is to control the excretion of salts and water, and to filter out metabolic end products from blood to preserve a proper environment for cells. This control process generates, under special conditions, complex behaviors such as self-sustained oscillations, period doublings and even chaos, in the evolution of proximal tubular pressure. These patterns can be explained from variation of the blood viscosity in the efferent arteriole, as result of glomerular filtration rate, which works as a bifurcation parameter. Classical studies apply one-dimensional bifurcation analysis to describe multistability, also associated to hypertension or high blood pressure.
\end{abstract}

\section{Challenge}

Actual single-nephron hemodynamic models do not take into consideration the dynamics of the blood viscosity in the efferent arteriole as an effector of the changes in the glomerulo-tubular balance. Proximal tubular reabsorption accounts for almost $70-75 \%$ of total water and salt reabsorption by the nephron and is an important factor in the control of salt balance and plays a role in the control of blood pressure, extracellular $\mathrm{pH}$ and many other variables. It was found that the viscosity in the blood emerging from the glomerulus affect proximal reabsorption. Many pathological states arise from alterations in tubular reabsorption, including hypertension and changes in blood viscosity can be detected in parallel with changes in cholesterol, polycythemia and SIADH among others.

\section{Contributions}

The nonlinear model is improved by the inclusion [1] of drag force and related pressure drop estimations, based on hydrodynamic equations describing the frictional effects of viscosity over the efferent arteriole walls. This allows the calculation of the blood viscosity at each time-instant from the values of the state variables, which may be available either from measurements or from model simulations run in parallel and online. The estimation of viscosity and shear stresses has wider implications in the understanding of the glomerulo-tubular balance inside the nephron [2].

In this paper, a system theoretic point of view is taken and it is shown that the dynamic behavior of the improved single-nephron model can be explained from variation of the blood viscosity in the efferent arteriole. Then, bifurcation diagrams for the most significant physical objects (the 
proximal tubular pressure and the radius of the efferent arteriole) with the efferent viscosity as bifurcation parameter are analyzed. From this characterization, normal and pathological levels related to eventual efferent viscosity changes are given precise quantitative bounds. Normal variations in viscosity range between 2 and 3 centipoises. Out from this range nonlinear oscillations begin to be distorted. The range is also expressed in terms of hematocrit levels in the blood, which is a more convenient pointer.

\section{$\underline{\text { References }}$}

1. S. Ditlevsen et al., 2005. Parameter estimation in a stochastic model of the tubuloglomerular feedback mechanism in a rat nephron. Mathematical Biosciences 194 49-69.

2. Lopardo, M., Diaz-Sylvester, P., Amorena, C., 2007. The effect of shear stress on the basolateral membrane potential of proximal convoluted tubule of the rat kidney. Pflugers Arch. 454:289-295 